\title{
INDIA's RAPE CRISIS: REDEFINING INDIA's RAPE LAWS BASED ON A CONSTRUCTIVE and Comparative Analysis of the Rape EPIDEMIC In INdia AND The United STATES
}

\author{
Ritika Singh \\ Nova Southeastern University Florida, USA
}

Rs2050@mynsu.nova.edu

SINGH, Ritika. India’s Rape Crisis: Redefining India's Rape Laws Based on a Constructive and Comparative Analysis of the Rape Epidemic in India and The United States. International and Comparative Law Review, 2019, vol. 19, no. 2, pp. 7-26. DOI: 10.2478/iclr-2019-0013.

\begin{abstract}
Summary: This Article addresses the rape epidemic in India and provides an analytical comparison to the rape laws in the United States. This Article provides an overview of the laws in both India and the United States and specifically discusses marital rape and the laws concerning it in both nations. This Article concludes with resolutions for the marital rape laws in India and the United States.
\end{abstract}

Keywords: India, United States, Marital Rape, Rape Laws

\section{Introduction}

Rape is rape, whether it occurs in the bedroom or in a public place. ${ }^{1}$ At common law, rape is defined as the "unlawful sexual intercourse committed by a man with a woman not his wife through force and against her will." 2 This common law definition of rape was established in the sixteenth century by England's Chief Justice Sir Mathew Hale, who stated, "the husband cannot be guilty of rape committed by himself upon his lawful wife." ${ }^{3}$ Women were treated as a man's property, thus rape was not a crime against women, but rather a violation of a man's property, which has made it complicated for women to have a place and voice in

1 Ritika Singh is an attorney licensed in Florida and a student at the University of Southern California pursuing her Entertainment Law Certificate. Ritika would like to thank her family and friends for their support in writing this article. NIGAM, Shalu. The Social And Legal Paradox Relating To Marital Rape In India: Addressing Structural Inequalities. [online]. Available at: <http://www.countercurrents.org/nigam030615.htm> Accessed: 09.25.2019.

2 LUTZ-PRIEFERT, Megan. A Call for a More Permanent International Definition of Rape, 6 Creighton International \& Comparative Law Journal, 2015, vol. 6, no. 85, p. 87.

3 JILOHA, R.C. From Rape to Sexual Assault: Legal Provisions and Mental Health Implications. [online]. Available at: <http://www.indjsp.org/text.asp?2015/31/1/9/161992> Accessed: 09.25.2019 
society today. ${ }^{4}$ Most people could not comprehend the notion that a man could rape his wife because in the eyes of society, men were deemed to be protectors of women. ${ }^{5}$ The modern definition of rape exempts the inclusion of the common law understanding that the victim must the wife of a man committing the rape offense. ${ }^{6}$ Therefore, this modern definition is a progressive approach in allowing women to have a voice not only in their households, but also in society.

Marital rape is a unique problem because women in marriages are subject to physical violence and the psychological trauma of being raped by someone who has taken marriage vows to love and honor his spouse. ${ }^{7}$ The marital rape exemption existed because common law defined rape as forced sexual intercourse with a woman not his wife. ${ }^{8}$ Thus, courts and society in general were extremely reluctant to acknowledge that rape of a spouse was the same criminal violation as rape of a stranger and deserved equal, or perhaps more severe punishment because the common law definition of rape did not extend to rape of a wife committed by her husband. ${ }^{9}$

After the 2012 Delhi gang-rape case was exposed to the media, women's rights and the issue of rape received heightened awareness. ${ }^{10}$ In May 2017, India's Supreme Court upheld the death sentences of four men who were convicted in a fatal gang-rape of a 23-year-old medical student on a moving bus which occurred in 2012. ${ }^{11}$ The outrage of the Delhi gang-rape case prompted India's

4 SIEGAL, Weintraub Lalenya. The Marital Rape Exemption: Evolution to Extinction, 43 Cleveland State Law Review, 1995, vol. 43, no. 351, p. 356.

5 WOOLLEY, Lee Morgan. Marital Rape: A Unique Blend of Domestic Violence and NonMarital Rape Issues, 2007, Hastings Women's Law Journal, vol. 18, no. 269, p. 272.

6 LUTZ-PRIEFERT' supra note 2 (The modern definition of rape is "Unlawful sexual activity ([especially] intercourse) with a person ([usually] a female) without consent and [usually] by force or threat of injury.")

7 WOOLLEY, supra note 5, p. 270.

8 Ibid. at 275; GODSOE, Cynthia. Why 20 States Treat Raping Your Wife As A Lesser Crime. [online]. Available at: <http://talkingpointsmemo.com/cafe/spousal-rape-lesser-crimein-20-states> (Historically, marital rape did not exist because women were traditionally deemed as a man's property) Accessed: 09.25.2019.

9 Woolley, supra note 5, p. 270; SITTON, Jaye. Old Wines in New Bottles: The Marital Rape Allowance, 1993, North Carolina Law Review, vol. 72, no. 261, p. 263. (the marital rape allowance creates a lesser crime for rape within a marriage compared to any other rape, which is why marital rape should be more narrowly defined to not allow husbands enjoy an unqualified privilege to force their wives to engage in nonconsensual sex).

10 KAPUR, Mallika, SINGH, Harmeet Shah. New Delhi rape exposes the perils of being woman in India. [online]. Available at: <http://www.cnn.com/2012/12/21/world/asia/indiarape-danger/> Accessed: 09.30.2019; Huffington Post, Delhi Bus Gang Rape Victim Has Intestines Removed As Shocking Details Of Assault Emerge. [online]. Available at: <http:// www.huffingtonpost.com/2012/12/20/delhi-bus-gang-rape-victim-intestines-shockingdetails_n_2340721.html> Accessed: 09.30.19

11 USA Today, 4 convicted in fatal gang-rape that shocked India will be hanged. [online]. Available at: <https://www.usatoday.com/story/news/world/2017/05/05/gang-rape-india- 
legislation to double the prison terms for rapists to twenty years. ${ }^{12}$ In light of the massive protests happening in India after the victim died two weeks after the rape occurred, the Indian government placed the gang-rape case on priority. ${ }^{13}$ Despite the Indian government's efforts to bring justice to the victim of the Delhi gang-rape case and her family, rape is still an issue at large in India because lawmakers cannot reasonably define rape or find a solution to the rape crisis. ${ }^{14}$ Globally, countries encounter difficulties in reaching a solution because of conflicting laws, culture, tradition, and societal norms. ${ }^{15}$

This article will begin by introducing marital rape and how the definition of marital rape has evolved. Then, this article will provide background information for both India and the United States and an analysis of the rape laws in both countries followed by an explanation of the laws and procedures in place for committing marital rape in both countries in their respective positions. Next, this article will compare marital rape issues and how the laws have impacted women and their future, and society in general, in both India and the United States. Then, this article will discuss traditions and culture that exists in society in both countries and how the issue of marital rape will be improved upon with a change in society's views and opinions. The article will then conclude with a brief recap of the information provided and changes or revisions that should be made to rape laws in its entirety.

\section{Laws and Events in India and the United States}

\subsection{India}

\subsubsection{Background}

India is a country situated in Southern Asia, with an area that is approximately one-third more than the size of the United States. ${ }^{16}$ It is a highly dense populated country, ranked second in the world in terms of population with $1,266,883,598$ billion people. ${ }^{17}$ The population growth rate is currently at $1.19 \% .{ }^{18}$ New Delhi is the capital of India and is the most densely populated urban city, followed by Mumbai, Kolkata, Bangalore, Chennai, and Hyderabad, in that respective order. ${ }^{19}$ According to the 2001 census, although English is the official language of

death-sentence/101320278/> Accessed: 09.25.2019

12 Ibid.

13 Ibid.

14 See KAPUR \& SINGH, supra note 10.

15 See LUTZ-PRIEFERT' supra note 2, p. 99.

16 The World Factbook, C.I.A. [online]. Available: <https://www.cia.gov/library/publications/resources/the-world-factbook/geos/in.html> Accessed on: 09.25.2019. [hereinafter CIA India].

17 Ibid.

18 Ibid.

19 Ibid. 
the country, Hindi is the most widely spoken with fourteen other widely spoken languages. ${ }^{20}$ Several religions exist in India, with the major religions including Hindus, Muslims, Christians, Sikhs, and other unspecified religions which hold a small percentage. ${ }^{21}$

The gender ratio is notable, where there is a pattern of more male than female from at birth to sixty-five years of age and older. ${ }^{22}$ The ratio for India's total population consists of 1.08 male(s) compared to female..$^{23}$ India currently stands as the forty-ninth country in the world in terms of infant mortality rate, where there are more female infant mortalities than males. ${ }^{24}$ Furthermore, the unemployment rate is also higher for women than men in India, with $11.6 \%$ female being unemployed compared to $10.4 \%$ male being unemployed in India. ${ }^{25}$

India has a federal parliamentary republic, which means that its cabinet members have the executive powers while the individuals are responsible for the legislature. ${ }^{26}$ India follows a common law system based on the English model, where separate personal codes apply to the different religions that exist in India. ${ }^{27}$ India faces several long-term challenges among which is discrimination against women and girls due to many factors including its population ratio and limited resources available considering its population. ${ }^{28}$

\subsubsection{Marital Rape Laws And Culture In India}

In India, "rape laws" began with the enactment of the Indian Penal Code (IPC) in $1860 .^{29}$ The IPC is criminal statute followed by the Indian justice system. ${ }^{30}$ The Indian Penal Code has exempted husbands from prosecution for raping their wives ever since the statutes have been established. ${ }^{31}$ Moreover, rape is one of the most common crimes in India. ${ }^{32}$ The Indian Penal Code section 498A

20 Ibid.

21 C.I.A. India, supra note 16 (Hinduism is the majority religion in India at 79.8 percent, followed by Islam at 14.2 percent, Christianity at 2.3 percent, Sikhism at 1.7 percent, and other unspecified religions at 2 percent).

22 Ibid.

23 Ibid.

24 Ibid. (For every 1,000 live births, 41.8 female deaths occur compared to 39.2 deaths for males in terms of infant mortalities in India).

25 Ibid.

26 C.I.A. India supra note 16; see also Merriam-Webster Online Dictionary. [online]. Available at: <https://www.merriam-webster.com/dictionary/parliamentary\%20government> Accessed: 09.25.2019

27 C.I.A. India, supra note 16.

28 Ibid.

29 JILOHA, supra note 3.

30 See Indian Penal Code, Act No. 45 of 1860, Pen Code (1860). [online]. Available at:

$<$ http://ncw.nic.in/> Accessed: 09.25.2019 [hereinafter IPC].

31 JILOHA, supra note 3.

32 Ibid. 
states: "Husband or relative of husband of a woman subjecting her to cruelty. Whoever, being the husband or the relative of the husband of a woman, subjects such woman to cruelty shall be punished with imprisonment for a term which may extend to three years and shall also be liable to fine." 33

Although the main objective of IPC section 498 is to protect women from harassment and cruelty from their husband, there is no standard for the Indian courts to measure or interpret the definition of "cruelty" within intimate spousal relations. ${ }^{34}$ Thus, the current law allows husbands to take advantage of the justice system and their marriage by harassing their wives without being subject to any repercussions for their actions.

In Bommallaiah v. State of Andra Pradesh, India, the court found the husband guilty under IPC section 325 , not IPC section $498 .{ }^{35}$ Most cases under IPC section 498 are based on a fabricated claim which involves blackmail attempts by the wife or her close relatives when faced with a strained marriage. ${ }^{36}$ High courts in India have suggested a "misuse" of the laws relating to violence against women, which is the reason why courts have been reluctant to enforce stricter laws for women subject to domestic violence. ${ }^{37}$ Thus, courts in India must thoroughly understand the facts of the case in order to make a reasonable determination of whether there has been a "misuse" of the laws based on a fabricated claim, or a legitimate fear of domestic violence. ${ }^{38}$

India is one out of forty-nine nations that do not criminalize marital rape. ${ }^{39}$ A 2013 United Nations report said that of 10,000 men surveyed in six countries, including India, 2,500 admitted to having raped a female partner. ${ }^{40}$ The report further noted that the most common motivation was sexual entitlement, in which men believe that they have a right to have sex with a woman regardless of consent due to their marital status. ${ }^{41}$ In India, the legal age for a woman to get married is eighteen-years-old. ${ }^{42}$ According to the Hindu Marriage Act of 1955 , it is not a crime to force conjugal relations in a marriage unless the bride is younger than fifteen-years-old. ${ }^{43}$ Evidently the text of the Hindu Marriage Act

33 IPC, supra note 30.

34 RAO, P P Jagadish, SHETTY, Aditi Suresh, KUMAR, B Suresh. Legal Terrorism in Domestic Violence - An Indian Outlook. Medico-Legal Journal. 2012, vol. 80, no. 33, p. 35.

35 Ibid.

36 Id. at p. 36.

37 Ibid.

38 See ibid.

39 SACHDEV, Chhavi. Rape Is A Crime In India - But There Are Exceptions, NPR.org. [online]. Available at: <http://www.npr.org/sections/goatsandsoda/2016/04/13/473966857/rape-isa-crime-in-india-with-one-exception > Accessed: 09.25.2019

40 Ibid.

41 Ibid.

42 Ibid.

43 The Hindu Marriage Act, No. 12 of 1955, HINDU CODE, Available at:

<http://highcourtchd.gov.in> Accessed: 09.25.2019; see also SACHDEV, supra note 39. 
of 1955 implicitly allows a marital rape exemption when having forced conjugal relations with a woman, unless the bride is younger than fifteen, but the legal age to marry is well above the age of fifteen. ${ }^{44}$ Although cruelty against women in marriages is recognized as reasonable grounds to consider it as a crime, the sexual torture within a marriage is not given the same weight, which is the underlying issue regarding marital rape. ${ }^{45}$

Marital rape in India stems from the outdated notion of marriage that regards wives as property of their husbands, and that the existence of a relationship is not a valid defense against sexual violation. ${ }^{46}$ India's Minister of State for Home Affairs, Haribhai Parathibai Chaudhary states that marriage is a "sacrosanct institution," which means that the concept of marital rape, as understood internationally, is not suitable for Indian context because of illiteracy, poverty, social customs and norms, and religious values that the Indian culture is built upon. ${ }^{47}$ The culture of 'silence,' 'tolerance', 'adjustment', and 'compromise' among women is propagated to save and respect the 'honor', the 'pride' and the 'values' of the Indian family, thus overlooking the fact that incest, violence, suicides, and murders are the price women must pay. ${ }^{48}$ This notion creates the outlook that men are presumed "licensed to rape" which exploits social customs and religious beliefs as a shield to endorse retrogressive ideologies and legitimizes sexual abuse. $^{49}$

India's Parliament recently turned down the Bill to criminalize marital rape..$^{50}$ If this Bill were passed, it would have set a strong precedent to transform the traditional Indian culture of suppressing abuse in marriage for the sake of family values and honor. As a result, it would have allowed a remedy for women who are subject to marital rape, regardless of their age. ${ }^{51}$ However, Parliament's rationale behind rejecting this Bill is the belief that marriage is a sacred institution and interfering with such idea would lead to a breakdown of marriages. ${ }^{52}$ Currently, there is no criminal remedy available for women who are repeatedly sexually assaulted by their husband for a prolonged period of time. ${ }^{53}$ As a result, women must continue to tolerate sexual assault in their marriage for the sake of family honor because the Indian government fears the outcome of interfering with the sacredness of a marriage if such a law were enacted to criminalize marital rape. Furthermore, the idea of failing to enact a law against marital rape ignores the

44 SACHDEV, supra note 39.

45 NIGAM, supra note 1.

46 Ibid.

47 Ibid.

48 Ibid.

49 Ibid.

50 NIGAM, supra note 1.

51 See ibid.

52 Ibid.

53 Ibid. 
reality that the role of the state in a democratic society is to protect the rights of women and citizens rather than safeguarding the marital institution. ${ }^{54}$

The non-interventionist approach followed by India when dealing with marital rape is considered discriminatory against women because this idea reduces women to be deemed as "property of men" thus demoralizing their existence as individuals with equal rights. ${ }^{55}$ Although India's constitution is founded upon equality, women still struggle to have a predominant voice in in their households and society. ${ }^{56}$ There is a direct correlation between gender oppression and the cultural dominance of men in the Indian culture. The disparity in the literacy rate for men and women in India support this contention that men surpass women in terms of literacy. ${ }^{57}$ In India, men surpass women in education by approximately $20 \%$ with only $60.6 \%$ of women over the age of fifteen being literate compared to $81.3 \%$ men. ${ }^{58}$ Another example of male dominance is seen in politics, where women hold only 6.7 seats in Parliament and only one out of twenty-six seats on India's Supreme Court bench. ${ }^{59}$ Thus, it is evident that the men have a stronger influence than women in most sectors in India's society, which has become the country's adopted culture.

In India, rape is one of the most common crimes. ${ }^{60}$ Most rapes go unreported because the rape victims fear retaliation or humiliation in India. ${ }^{61}$ According to the National Crime Records Bureau Annual Report 2013, out of the 24,923 rape cases reported across the country in 2012, the victim knew the alleged rapist in $98 \%$ of the cases. ${ }^{62}$ However, India has a lower rate of reported rape compared to other developed or developing countries. ${ }^{63}$ Even though $96 \%$ of rape cases led to the offender being charged and prosecuted, many cases remained pending in its trial process in 2012, which floods the court system and the leaves the sexually abused wives with prolonged emotional and mental trauma. ${ }^{64}$

54 Id.

55 NIGAM, supra note 1.

56 NUSSBAUM, Martha C. India: Implementing Sex Equality Through Law. Chicago Journal of International Law. 2001, vol. 2, no. 38 p. 39.

57 Id. at 39; see also Women in the Labour Force: India, Catalyst, [online]. Available at: <http:// www.catalyst.org/knowledge/women-labour-force-india> Accessed: 09.30.2019

58 CATALYST, supra note 57.

59 NUSSBAUM, supra note 56.

60 JILOHA, supra note 3.

61 Ibid.

62 Ibid.

$63 \mathrm{Ibid}$. (noting that Delhi's rate of reported rape, 4.1/100,000 is found to be the highest in the country).

64 Ibid. 


\section{The United States}

\subsubsection{Background}

The United States is located in North America, between Canada and Mexico. ${ }^{65}$ It's territory includes fifty states and the District of Columbia, ranging about half the size of Russia and about three-tenths the size of Africa. ${ }^{66}$ As of 2016, the United States' population is $323,995,528$ million, placing it at the world's fourth highest populated country. ${ }^{67}$ The United States is a melting pot, with approximately eight different ethnic groups. ${ }^{68}$ There are over eight religions that exist in the United States. ${ }^{69}$ The Protestant and Roman Catholic religions are the majority in the United States, followed by Morman, Jehovah's Witness, other Christian, Jewish, Muslim, Buddhist, Hindu, and other, unaffiliated or refused religions, in that respective order. ${ }^{70}$

The gender ratio in the United States is predominately male from $0-14$ years of age to sixty-five years of age and over. ${ }^{71}$ Moreover, the total population in the United States is predominately male, being .97 male(s) compared to females. ${ }^{72}$ The infant mortality rate in the United States is higher for males than females. ${ }^{73}$ The United States currently ranks at 169 in the world in terms of infant mortality rate. ${ }^{74}$ As of 2014 , the unemployment rate is also higher for males than females, where $14.5 \%$ of men are unemployed compared to $12.2 \%$ of women unemployed..$^{75}$ The United States is currently ranked as the sixty-eighth country in terms of unemployment. ${ }^{76}$

The United States has a constitutional federal republic, which means that it favors a strict interpretation of the Constitution to restrict powers of the federal

65 The WorldFactbook, C.I.A., [online]. Available at: <https://www.cia.gov/library/publications/the-world-factbook/geos/us.html> Accessed: 09.25.2019. [hereinafter C.I.A. U.S.].

$66 \mathrm{Ibid}$. (The United States is the world's third-largest country by size).

67 Ibid.

$68 \mathrm{Ibid}$. (The ethnic groups in the United States include: white [79.96\%], black [12.85\%], Asian [4.43\%], AmeriIndian and Alaska native 0.97 percent], native Hawaiian and other Pacific islander $0.18 \%$ ], and two or more races $1.61 \%$ ]. A separate listing for Hispanics is not included in the US Census Bureau because it considers Hispanic to means persons of Spanish/Hispanic/Latino origin living in the United States who may be of any race or ethnic group. Thus, $15.1 \%$ of the total United States population is Hispanic).

69 Ibid.

70 C.I.A. U.S., supra note 65.

71 Ibid.

72 Ibid.

73 Ibid.

74 Ibid.

75 C.I.A. U.S., supra note 65.

76 Ibid. 
government. ${ }^{77}$ The capital of the country is Washington, DC. ${ }^{78}$ The United States follows a common law system based on English common at the federal level and the state legal systems are based on common law except for the state of Louisiana, which is based on Napoleonic civil code. ${ }^{79}$ In terms of its international law organization participation, the United States withdrew acceptance of compulsory International Court of Justice jurisdiction in 2005 and withdrew acceptance of the International Council on Clean Transportation in 2002. ${ }^{80}$

\subsubsection{Marital Rape Laws And Culture In The United States}

In the early 1980's, only ten states had an absolute marital rape exemption where a husband could never be prosecuted for raping his wife so long as the parties were legally married. ${ }^{81}$ Today, three main categories of marital rape exemption law exist. ${ }^{82}$ The first category provides the least protection to married women, where a husband cannot be prosecuted unless the couple is living apart, legally separated or filed for divorce or order of protection..$^{83}$ The second category is a partial exemption, where husbands are charged with a lesser crime of rape and in only certain circumstances can be prosecuted.$^{84}$ The third category, which provides the most protection to married women, is where there is no marital rape exemption and states have chosen to make no distinction between "marital rape" and non-marital rape." ${ }^{35}$ As times have changed, so has the law. In the twentieth century where women are presumed to be equal, historical justifications for the marital rape exemption no longer had legitimacy ${ }^{86}$ Historically, marriage was deemed to be a contract which exempted husbands from prosecution or criminal liability for raping his wife. ${ }^{87}$ At common law, women were treated as man's

77 Ibid.; see also Merriam-Webster Online Dictionary. [online]. Available at: <https://www. merriam-webster.com/dictionary/Democratic-Republican> Accessed: 09.30.2019

78 C.I.A. U.S., supra note 65.

79 Ibid.

80 Ibid.

81 SIEGEL, supra note 4, at 367; Commonwealth v. Fogerty, 8 Gray 489, 491 (Mass. 1857) (noting that in 1857, Massachusetts was the first state to recognize the common law marital rape exemption, which created a defense to rape occurring between married individuals).

82 SIEGEL, supra note 4 , at 368 .

$83 \mathrm{Ibid}$. (noting that only four states recognize the first category of marital exemption law which provides the lease protection to married women: Kentucky, Missouri, Oklahoma, and South Carolina).

$84 \mathrm{Ibid}$. at 368-69 (A total of twenty-four states fall into the second category of marital exemption law, where sixteen states exempt husbands from prosecution of rape that does not involve force or threat of force. These sixteen states are as follows: Arizona, California, Connecticut, Delaware, Hawaii, Idaho, Illinois, Iowa, Kansas, Maryland, Nevada, Ohio, Pennsylvania, Tennessee, Washington, and Wyoming.).

$85 \mathrm{Ibid}$. at 369 (noting that the remaining twenty-two states have completely abolished the marital rape exemption).

86 SIEGEL, supra note 4, at 358 .

87 Ibid. at 357. 
property. ${ }^{88}$ Thus, rape was not a crime against women, but rather a violation of a man's property interest. ${ }^{89}$

However, certain landmark cases changed the outlook on marital rape in the United States. In People v. Liberta, the New York Court of Appeals observed that a married woman has the same right to control her own body as does an unmarried woman. ${ }^{90}$ The court in Liberta did not give great deference to the legislature and its poorly constructed statute because it was based on gender discrimination and instead, enacted a new rape statute which abolished the marital rape exemption and penalized those who commit rape, regardless of gender or marriage. ${ }^{91}$ According to Liberta, the purpose behind the early rape laws was to protect the chastity of women. ${ }^{92}$ Currently, People v. Liberta stands as the law for marital rape in the United States, however, not all states follow this law to abolish marital rape in an unified manner. ${ }^{93}$

Another landmark case regarding marital rape, State v. Rideout, encouraged women to campaign for the abolishment of the marital rape exemption in those states where a husband could not yet be prosecuted for raping his wife. ${ }^{94}$ States have made attempts to move towards abolishing the marital rape exemption and providing women with a remedy for the emotional, physical, and psychological trauma they have suffered. ${ }^{95}$ However, several states that still allow the marital rape exemption accord to social attitudes and traditional justifications where courts were extremely reluctant to acknowledge that rape of a spouse was the same criminal violation as rape of a stranger deserving equal or perhaps more severe punishment. ${ }^{96}$ The United States faces a unique problem - marital rape is not recognized or treated differently from non-marital rape. ${ }^{97}$ Marital rape has blended with domestic violence and is considered a private issue between a husband and a wife where it is masked as part of traditional cultural norms. ${ }^{98}$ This

88 Ibid. at $356-57$.

89 Ibid.

90 Griswold v. Connecticut, 381 U.S. 469, 486 (1965) (noting that the Supreme Court only extended the right to marital privacy to include consensual acts); see also People v. Liberta, 152 N.E.2d 567, 573 (N.Y. 1984).

91 SIEGEL, supra note 4, at 366-67.

92 Case Comment, To Have and to Hold: The Marital Rape Exemption and the Fourteenth Amendment. Harvard Law Review, 1986, vol. 99, no. 1255, pp. 1257-58 n.13 (In other words, the law was made to protect a father's interest in his daughter's virginity and a husband's interest in his wife's fidelity).

93 WOOLLEY, supra note 5, at 280.

94 SIEGEL, supra note 4, at 364-65.

95 See ibid. at 368-69; Commonwealth v. Chretien, 417 N.E.2d 1203, 1205 (Mass. 1981) (The court in Commonwealth v. Chretien held that the fact that the victim was the spouse of the defendant was no bar to a conviction of rape).

96 WOOLLEY, supra note 5 , at 276.

97 See ibid. at 274.

98 See ibid. at $290-91$. 
does not provide an adequate avenue for women to seek justice for the psychological, emotional, and physical trauma they suffer in their marriage. ${ }^{99}$

\section{Comparative Analysis of the Law}

\subsection{Differences}

While there are differences between India and the United States, these differences are not extreme. Cultural relativism is the notion where society's individual culture governs the rights and rules that society follows. ${ }^{100}$ India has adopted a cultural norm where women are expected to be more conservative and are forced to stay in an abusive marriage for the sake of their family's reputation, whereas in the United States, women have more freedom in their behavior and actions. ${ }^{101}$ Also, in the United States, women have the opportunity to make choices for themselves rather than in India where their families are their voice.

India's conservative culture has evolved as women remain silent in an abusive relationship in fear of shaming her family's honor. ${ }^{102}$ Currently, there is no criminal remedy available for women who are repeatedly sexually assaulted by their husband for a prolonged period of time. ${ }^{103}$ Most sexual violence in India occurs during marriage, where only $10 \%$ of married women report sexually violent behavior that occurs in their marriage. ${ }^{104}$ This may be the case because the law in India bestows an absolute immunity to the husband in respect to his wife, solely on the basis of the marital relation, or because women fear backlash from their family if they report sexual violence. ${ }^{105}$

Although India's Constitution is founded upon equality, women still struggle to have a predominant voice in society. ${ }^{106}$ The International Labour Organization reports a decline in the percentage of women in the labor force in India since 1990 to $2016 .{ }^{107}$ Compared to the United States, where $45.76 \%$ of the women are in the labor force, only $24.28 \%$ of women are enrolled in the labor force in India. ${ }^{108}$ These numbers confirm a correlation between gender inequality in both

99 Ibid. at 291.

100 LUTZ-PRIEFERT, supra note 2 , at 87.

101 NIGAM, supra note 1; LUTZ-PRIEFERT, supra note 2.

102 NIGAM, supra note 1.

103 MCDOUGAL, Lotus, RAJ, Anita. Sexual violence and rape in India. [online]. Available at: <http://www.thelancet.com/pdfs/journals/lancet/PIIS0140-6736(14)60435-9. pdf.>Accessed: 09.30.2019

104 Ibid.

105 See ibid.

106 India Constitution. art. 14 (Article 14 of India's Constitution establishes that the "State shall not deny to any person equality before the law or the equal protection of the laws within the territory of India."); see NUSSBAUM, supra note 56, at 37.

107 THE WORLD BANK. [online]. Available at: $<$ http://data.worldbank.org/indicator/SL.TLF. TOTL.FE.ZS?end=2016\&locations=IN-US\&start=2016\&view=bar $>$ Accessed: 09.30.2019 108 Ibid. 
countries and how outside factors aside from marital rape laws are also affected by a country's cultural relativism. Despite the increased number of women joining the workforce in the United States, women are still paid seventy-nine cents for every dollar paid to men. ${ }^{109}$ This gender pay gap is affected by gender bias and societal views of how men still hold the predominant roles in society. ${ }^{110}$

However, the gender pay gap remains an issue across the globe. ${ }^{111}$ In India, this gap is wider with men earning 167 dollars for every 100 dollars earned by women. ${ }^{112} \mathrm{~A}$ major reason that creates a pay gap in employment for women in India is the cultural and social issues. ${ }^{113}$ Several equalizers, such as guidance and career strategies, can be implemented to help bridge the gender pay gap and allow more women to join the working population. ${ }^{114}$ Even though both countries recognize a gender pay gap, India has employed a wider pay gap, which significantly affects its women by implicitly supporting the idea of oppression. ${ }^{115}$

Gender oppression has been a longstanding matter in India well before marital rape developed to be an issue. Despite women now asserting their autonomy within their natal and marital homes, certain ideologies still remain amongst society, whether it is in politics, economic, or social narratives to justify gender, caste, class hierarchies and racial divides. ${ }^{116}$ Religion has played a profound role in influencing gender oppression in India for centuries. ${ }^{117}$ According to the Hindu Doctrine, the role of women was "simply to support the man and enable him to continue his family tradition." 118 Traditional practices such as female infanticide which involve pain and suffering to women was widely acknowledged in India and has set a heavy precedent that women are seriously undervalued and were

109 GOULD, Elise, SCHIEDER, Jessica. "Women's work" and the gender pay gap. [online]. Available at: <http://www.epi.org/publication/womens-work-and-the-gender-pay-gaphow-discrimination-societal-norms-and-other-forces-affect-womens-occupational-choices-and-their-pay/> Accessed: 09.30.2019

110 Ibid.

111 AYYAR, Ranjani. Women can match men's pay after 150 years!, The Times of India. [online]. Available at: <http://timesofindia.indiatimes.com/india/women-can-match-mens-payafter-150-years/articleshow/57528707.cms> Accessed 09.30.2019

112112 Ibid.

113 Ibid.

114 Ibid.

115 Ibid.

116 KRISHNAN, Kavita. Rape Culture and Sexism in Globalising. Sur International Journal On Human Rights, 2015, vol. 22 no. 255, p. 256.

117 BUCKLEY, Alex. Gender Oppression, inequality and Gender Roles In India and Southwestern United States: How British Colonial Rule and American Internal Colonialism Perpetuated Gender Roles and Oppression. [online]. Available at: <https://people.smu.edu/ knw2399/2015/04/30/gender-oppression-inequality-and-gender-roles-in-india-andsouthwestern-united-states-how-british-colonial-rule-and-american-internal-colonialism-perpetuated-gender-roles-and-oppression/> Accessed: 09.30.2019

118 Ibid. 
placed in the margins of society. ${ }^{119}$ In the ancient times, women were associated with the lowest caste and in lower classes were subjected to violence to maintain gender inequality. ${ }^{120}$ Although these views have significantly diminished, men are still presumed to have the dominant role in India's society. ${ }^{121}$

Unlike in India, where women are suppressed by virtue of the law and cultural norms, women in the United States have more freedom in terms of pursuing an education without fear of being attacked or being forced into marriage at a young age. ${ }^{122}$ The United States Supreme Court has ruled that "Nowhere. . . is a woman regarded as chattel or demeaned by denial of a separate legal identity and the dignity associated with recognition as a whole human being." ${ }^{123}$ Despite the United States' efforts in promoting gender equality, women still face adversity in society. ${ }^{124}$ Surveys show that nearly two-thirds of minimum wage earners are women. ${ }^{125}$ The status of women in the United States is extremely complex because full gender equality is not yet achieved. ${ }^{126}$

Therefore, this issue must be reassessed to achieve full gender equality in both the United States and India. Efforts to promote gender equality is a positive step in ensuring that women are given an equal opportunity in society whether it is in education, politics, or business affairs. These efforts will encourage the legislature to provide an avenue for women who are suffering an abusive relationship by modifying the definition of marital rape in order to allow husbands to be held criminally liable for their actions.

Although the United States has made active efforts to move towards more states abolishing the marital rape agreement, several states still rely on tradi-

$119 \mathrm{Ibid}$. (noting that female infanticide is the act of killing newly born female infants); Delhi rapist says victim shouldn't have fought back, BBC News (Mar. 3, 2015), ht p:// www.bbc.com/news/magazine-31698154 (Gender inequality significantly contributes to rape and female infanticide, which is a huge problem embedded in India's roots).

120 BUCKLEY, supra note 117.

121 How the dominant man subjugates other men, women and society, [online]. Available at: $<$ http://www.orfonline.org/research/how-dominant-man-subjugates-men/> Accessed: 09.30.2019

122 RAVITZ, Jessica. Women in the World: Where the U.S. Falters in quest for equality. [online]. Available at: <http://www.cnn.com/2015/04/16/us/american-women-world-rankings/ index.html> Accessed: 09.30.2019

123 Trammel v. United States, 45 U.S. 40, 52 (1980); see, e.g. People v. DeStefano, 467 N.Y.S.2d 506, 512 (Suffolk County Ct. 1983) (the court in People v. DeStefano noted that rape is perceived as a truly violent crime, even when "accomplished behind the veil of a marriage license.").

124 CRARY, David. Divided America: Gender equality in 2016? It's complicated. [online]. Available at: <https://apnews.com/9eb970efc58042b5a4aeda76fd4e7123/divided-america-gender-equality-2016-its-complicated $>$ Accessed: 09.30.2019

125 Ibid.

126. SMILOWITZ, Ariel. For U.S. Women, Inequality Takes Many Forms. [online]. Available at: $<$ http://www.huffingtonpost.com/ariel-smilowitz/for-us-women-inequality-takes-manyforms_b_7064348.html > Accessed: 09.30.2019 
tional justifications to impose some degree of marital rape exemption to allow husbands to escape criminal liability in instances where a wife is sexually abused in her marriage. ${ }^{127}$ India has a completely different stance on marital rape and does not anticipate a change in the law to abolish marital rape because the legislature does not want to interfere between a husband and wife based on the belief that a marriage is a sacred institution. ${ }^{128}$ Both countries have a distinct view on marital rape, which is supported by each county's respective cultural relativism in terms of the law, education, and jobs. ${ }^{129}$ Therefore, the cultural norm and gender inequality issues in each country plays a significant role in determining the law and future for its women and whether husbands should be held criminally liable in cases involving marital rape. ${ }^{130}$

\subsection{Similarities}

Both United States and India have multi-cultural societies which is influenced by its democratic government. ${ }^{131}$ Multiculturalism is defined as "the state of co-existence of diverse cultures" which includes race, religions, and languages. ${ }^{132}$ Although India's Constitution assigns equal rights and privileges to all people in India regardless of their gender, case, community, class, or religion, it still faces challenges to bring various communities into the mainstream society in efforts to promote multiculturalism. ${ }^{133}$

Similarly, the United States is founded upon principles of religious freedom provided by its Constitution and the Bill of Rights. ${ }^{134}$ Further, the American religious freedom always included religious freedom, which is the "willingness to let religious groups live free of deliberate prosecution." ${ }^{135}$ Given the fact that the United States is a "melting pot" of cultures, experiences with different cultures helps promote unity and cultural awareness in the United States. ${ }^{136}$ More cultural awareness allows individuals to become more respective and tolerant towards others regardless of their race, ethnicity, gender, or class.

127 SIEGEL, supra note 4, at 365-67.

128 NIGAM, supra note 1.

129 WOOLLEY, supra note 5; see also SACHDEV, supra note 39.

130 WOOLLEY, supra note 5; see also SACHDEV, supra note 39.

131. Multiculturalism and India. [online]. Available at: < <ttp://socialsciences.in/article/multiculturalism-and-india> Accessed: 09.30.2019

132 DOMINIC, K.V. Multiculturalism in India: A Wonder to the World. [online]. Available at: <http://profkvdominic.blogspot.com/2016/04/multiculturalism-in-india-wonder-to. html> Accessed: 09.30.2019

133 Ibid.

134 VOLOKH, Eugene. The American tradition of multiculturalism. [online]. Available at: $<$ https://www.washingtonpost.com/news/volokh-conspiracy/wp/2015/01/27/the-americantradition-of-multiculturalism/?utm_term=.e41a07156ecc $>$ Accessed: 09.30.2019

135 Ibid.

136 See ibid. 
Both countries still recognize the marital rape exemption to some extent. ${ }^{137}$ In the United States, approximately thirty states have not abolished the marital rape exemption, relying on several justifications, most of which are based on traditional views on marriage. ${ }^{138}$ Like India, marriage in the United States has been traditionally viewed to be a private family practice. ${ }^{139}$ This traditional notion was established in the sixteenth century with Lord Matthew Hale's declaration that a "husband cannot be guilty committed by himself upon his lawful wife," based on the theories of implied consent and a contractual relationship between a husband and wife. ${ }^{140}$

Thus, marital rape was a foreign concept because women were actually considered to be a man's property, not his wife. ${ }^{141}$ This belief is embedded in India's culture as well as in the United States to some degree where states still recognize the marital rape exemption. ${ }^{142}$ In order to end woman's suffrage in their marriage, both countries must take proactive steps in ensuring that women do not suffer in their bedrooms based on the legislature's denial of recognizing marital rape as a serious issue.

\section{Resolution}

The marital rape exemption serves as both a "manifestation and a vehicle for the continued subordination of women in society." 143 Gender inequality exists in both the United States and India in their own respective ways, which has a direct correlation to marital rape in both countries. ${ }^{144}$ Women have been suppressed in both countries and the marital rape laws have been an example of this. ${ }^{145}$ Society should not attempt to protect a decaying and violent marriage by suggesting to reconciliation at the expense of a woman's abuse. ${ }^{146}$ Marital rape in the United States has been given greater significance as it has been revisited by the U.S. courts and legislators, which has transcended into this issue taking an increasing importance internationally. ${ }^{147}$ However, taking the issues on a global level can often lead marital rape into entanglement with more complex matters where it becomes undistinguishable from domestic violence or non-marital rape. ${ }^{148}$ Although marital rape encompasses characteristics of domestic violence, it should not be categorized as the same because of the far more severe psycho-

137 See SIEGEL, supra note 4, at 365-67; see also SACHDEV supra note 39.

138 See SIEGEL, supra note 4, at 365-67.

139 Case Comment, supra note 92, at 1257-58.

140 See WOOLLEY, supra note 5, at 275-76.

141 See ibid.

142 RAVITZ, supra note 122.

143 Case Comment, supra note 92, at 1255.

144 BUCKLEY, supra note 117; see also CRARY, supra note 124.

145 SIEGEL, supra note 4, at 365-67; see also SACHDEV, supra note 39.

146 SEIGEL, supra note 4 , at 362 .

147 WOOLLEY, supra note 5, at 269.

148 .Ibid. 
logical effects it has on a wife who has made vows to love and honor with her husband that has committed rape within the marriage. ${ }^{149}$

Marital rape is a distinctive problem that requires a separate analytical framework than the issues of domestic violence or non-marital rape. ${ }^{150}$ Moreover, alternative remedies, such as divorce are inadequate because it does not provide the same relief. ${ }^{151}$ The United States' legislature should not undermine marital rape by applying the approach that marital rape does not occur enough for society to recognize it as a problem or that there is less severe damage involved compared to a victim of non-marital rape. ${ }^{152}$ If all states were to follow an absolute abolishment of the marital rape exemption, then violence against women would significantly be eliminated and preventive legal and legislative measures would provide women with the opportunity to be relieved from a strained marriage. ${ }^{153}$ The legislature is an important source to change the societal norms and perceptions, which can make an impact when reforming the laws in place. ${ }^{154}$ The aftermath of marital rape leaves a woman with betrayal and disillusionment that breaks down the relationship between a husband and wife. ${ }^{155}$ Moreover, women are faced with a life full of fear with the fact that rape may be repeated for several years and as a result, leave her to stay in a relationship with a man she has entrusted. ${ }^{156}$

Marital rape is far more problematic in India because of the tradition and culture that is rooted in its society. ${ }^{157}$ The foundations of marriage in India are built around a man's entitlement of his wife as his "property" which is exchanged from the father of the bride to the bride's new husband. ${ }^{158}$ Despite this idea becoming far less prevalent, where women are now asserting their autonomy within their marital homes and respective careers, certain ideologies still exist among society, whether it is in politics, economics or social narratives to justify the gender gap, class hierarchies, and racial divides. ${ }^{159}$ Perhaps the most effective way to make a substantial change in marital rape laws is to change the underlying social conditions which has fostered spousal immunity. ${ }^{160}$

149 See ibid. at 270.

150 SIEGEL, supra note 4, at 363.

151 Ibid.

152 See ibid.

153 Ibid. at 364.

154.WORLD HEALTH ORG., Changing culture and social norms that support violence. [online]. Available at: http://www.who.int/violence_injury_prevention/violence/norms. pdf> Accessed: 09.30.2019

155 NIGAM, supra note 1.

156 Ibid.

157 Ibid.

158 Ibid.

159 KRISHNAN, supra note 116, at 258.

160 SIEGEL, supra note 4 , at 377. 
The United States has provided much more freedom and opportunity to women because of its less restrictive laws, cultural relativism, and customs. ${ }^{161}$ Whereas in India, women have a difficult time voicing their opinion and holding a prominent position in society because of its scrutinized laws, conservative culture, and tradition. ${ }^{162}$ However, India should not compromise its culture or tradition that has been followed and respected for centuries in order to reform marital rape laws. A starting point for making an impact in marital rape laws and the perception of women in general in society is to take proactive measures such as criminalizing marital rape or modify the underlying social conditions that have fostered spousal immunity. ${ }^{163}$ This would provide a reform in the laws as well as taking measures to lessen the gender gap.

There is a deeply embedded sexist ideology about women's sexuality, which supports the common law justifications that a woman is a man's "property." ${ }^{164}$ This deeply embedded sexist ideology has fostered violence against women and justified the marital rape exemption for ages. ${ }^{165}$ India’s laws pertaining to rape has become long overdue for review. ${ }^{166}$ While India has become globalized on many fronts, its laws governing violence against women "remain archaic." 167 Moreover, there is a wide gap between the ideologies that exist in rural India compared to the urban areas, where victims are left with little or no justice. ${ }^{168}$ Along with a reform in India's laws and legislative intent to abolish the marital rape exemption, its society must diminish the stigma that lies with a woman's body and portray a woman's role with respect, dignity, and honor, which will cast away the preconceived notions that lies within the culture.

\section{Conclusion}

As demonstrated, the United States has been taking proactive measures to abolish the marital rape exemption by a majority of the states abolishing the marital rape exemption, however, this abolishment must occur in a unified manner in all states. States that still recognize the marital rape exemption should adapt a statutory framework which criminalizes marital rape by defining rape as "an act of sexual intercourse accomplished with a person including the spouse." ${ }^{169}$

161 Case Comment, supra note 92.

162 NIGAM, supra note 1.

163 Ibid.

164 Ibid.

165 See ibid.

166 RAI, Saritha. India: Reforming rape laws. [online]. Available at: <https://www.pri.org/stories/2010-10-29/india-reforming-rape-laws > Accessed: 09.30.2019

167 Ibid.

168 Ibid.

169 ANDERSON, Michelle J., Marital Immunity, Intimate Relationships, and Improper Inferences: A New Law on Sexual Offenses By Intimates, Hastings Law Journal, 2003, vol. 54, p. 1533; MILLER, Jeremy M. Mens Rea Quagmire: The Conscience or Consciousness of the Criminal Law. Western State University Law Review, 2001, vol. 29, no. 1, p. 46. (Before 
Reforming the definition of rape as such would enact a statute that would not only clarify sexual offense laws, but would also allow women the opportunity to be free of a decaying and violent marriage. ${ }^{170}$ Furthermore, adapting a refined definition of marital rape would remove the outdated justifications for such an exemption that demoralizes a woman's bodily integrity.

The ongoing marital rape crisis in India can be resolved by changing the underlying social conditions that creates an unjust divide between men and women. Women are expected to remain silent in abusive relationships in order avoid divorce and uphold her family's honor and social status. ${ }^{171}$ This approach, however, does not safeguard women in their homes nor does it prevent sexual violence that a victim is subjected by their spouse. Silence should not be encouraged in an abusive marriage where women must endure violence in the name of family honor. Therefore, India must refine its underlying social conditions and customs before reforming its marital rape laws in order to provide an appropriate avenue for justice to women in these circumstances and reduce the number of reported rapes.

Internationally, there is no permanent definition of rape that is recognized among all countries. ${ }^{172}$ Adopting an international definition of rape, without distinguishing it from rape occurring outside of marriage, can overall lower the number of reported rapes occurring in countries across the world, especially in countries like India where there is no recognition of marital rape laws. ${ }^{173}$ In addition, this approach would eliminate any discrepancies or confusion in marital rape laws among countries around the globe if there were an international definition of marital rape. ${ }^{174}$ Perhaps a more modern definition which exempts the inclusion of the common law understanding that the victim must be a woman that is not the wife of the man committing the rape offense would diminish the outdated justifications and negative ideology regarding women and their value in society. ${ }^{175}$ These changes can make a tremendous impact by not only reducing

marital rape evolved, at statutory rape, men could be convicted of rape by proving the "unlawfulness," which was established by the "general blameworthy state of mind of having non-consensual sex with an unmarried woman.”); Cal. Penal \$262(a)(1) (West 2002) (certain codes in the United States have additional requirements for a spouse reporting rape within a marriage to obtain relief, such as in California, where rape is accomplished by means of force, violence, duress, menace, or fear of immediate and unlawful bodily injury); S.C. Code. Ann. $1976 \$ 16-3-615$ (crime of a spousal sexual battery must be reported within thirty days); Minn. Stat. Ann. $\$ 609.349$ (West 2002) (the "legal spouse" term does not include when couple is living apart and one has filed for legal separation or dissolution of marriage).

170 ANDERSON, supra note 169, at 1540.

171 SACHDEV, supra note 39.

172 LUTZ-PRIEFERT' supra note 2, at 95.

173 See ibid.

174 See ibid.

175 See SIEGEL, supra note 4, at 374-75. 
the number of reported rapes occurring in a marriage, but also by bridging the gap in the gender equality that exists in today's society.

\section{References}

ANDERSON, Michelle J., Marital Immunity, Intimate Relationships, and Improper Inferences: A New Law on Sexual Offenses By Intimates, Hastings Law Journal, 2003, vol. 54, pp. 1463-1572.

AYYAR, Ranjani. Women can match men's pay after 150 years!, The Times of India. [online]. Available at: <http://timesofindia.indiatimes.com/india/women-can-match-menspay-after-150-years/articleshow/57528707.cms> Accessed 09.30.2019

BUCKLEY, Alex. Gender Oppression, inequality and Gender Roles In India and Southwestern United States: How British Colonial Rule and American Internal Colonialism Perpetuated Gender Roles and Oppression. [online]. Available at: $<$ https://people.smu. edu/knw2399/2015/04/30/gender-oppression-inequality-and-gender-roles-in-indiaand-southwestern-united-states-how-british-colonial-rule-and-american-internalcolonialism-perpetuated-gender-roles-and-oppression/> Accessed: 09.30.2019

CRARY, David. Divided America: Gender equality in 2016? It's complicated. [online]. Available at: <https://apnews.com/9eb970efc58042b5a4aeda76fd4e7123/dividedamerica-gender-equality-2016-its-complicated> Accessed: 09.30.2019

DOMINIC, K.V. Multiculturalism in India: A Wonder to the World. [online]. Available at: $<$ http://profkvdominic.blogspot.com/2016/04/multiculturalism-in-india-wonder-to. html> Accessed: 09.30.2019

GODSOE, Cynthia. Why 20 States Treat Raping Your Wife As A Lesser Crime. [online]. Available at: <http://talkingpointsmemo.com/cafe/spousal-rape-lesser-crime-in20-states> Accessed: 09.25.2019.

GOULD, Elise, SCHIEDER, Jessica. "Women's work" and the gender pay gap. [online]. Available at: <http://www.epi.org/publication/womens-work-and-the-gender-paygap-how-discrimination-societal-norms-and-other-forces-affect-womens-occupational-choices-and-their-pay/> Accessed: 09.30.2019

How the dominant man subjugates other men, women and society, [online]. Available at: <http://www.orfonline.org/research/how-dominant-man-subjugates-men/> Accessed: 09.30.2019

Huffington Post, Delhi Bus Gang Rape Victim Has Intestines Removed As Shocking Details Of Assault Emerge. [online]. Available at: <http://www.huffingtonpost.com/2012/12/20/ delhi-bus-gang-rape-victim-intestines-shocking-details_n_2340721.html> Accessed: 09.30.19

JILOHA, R.C. From Rape to Sexual Assault: Legal Provisions and Mental Health Implications. [online]. Available at: <http://www.indjsp.org/text.asp?2015/31/1/9/161992> Accessed: 09.25.2019

KAPUR, Mallika, SINGH, Harmeet Shah. New Delhi rape exposes the perils of being woman in India. [online]. Available at: <http://www.cnn.com/2012/12/21/world/asia/ india-rape-danger/> Accessed: 09.30.2019

KRISHNAN, Kavita. Rape Culture and Sexism in Globalising. Sur International Journal On Human Rights, 2015, vol. 22 no. 255, p. 256.

LUTZ-PRIEFERT, Megan. A Call for a More Permanent International Definition of Rape, 6 Creighton International \& Comparative Law Journal, 2015, vol. 6, no. 85, p. 87.

MCDOUGAL, Lotus, RAJ, Anita. Sexual violence and rape in India. [online]. Avail- 
able at: <http://www.thelancet.com/pdfs/journals/lancet/PIIS0140-6736(14)60435-9. pdf.>Accessed: 09.30.2019

Merriam-Webster Online Dictionary. [online]. Available at: <https://www.merriam-webster.com/dictionary/Democratic-Republican> Accessed: 09.30.2019

MILLER, Jeremy M. Mens Rea Quagmire: The Conscience or Consciousness of the Criminal Law. Western State University Law Review, 2001, vol. 29, no. 1, pp. 21-56.

NIGAM, Shalu. The Social And Legal Paradox Relating To Marital Rape In India: Addressing Structural Inequalities. [online]. Available at: <http://www.countercurrents.org/ nigam030615.htm> Accessed: 09.25.2019.

NUSSBAUM, Martha C. India: Implementing Sex Equality Through Law. Chicago Journal of International Law. 2001, vol. 2, no. 38 p. 39.

RAI, Saritha. India: Reforming rape laws. [online]. Available at: $<\mathrm{https} / / \mathrm{www} . p r i . o r g /$ stories/2010-10-29/india-reforming-rape-laws $>$ Accessed: 09.30.2019

RAO, P P Jagadish, SHETTY, Aditi Suresh, KUMAR, B Suresh. Legal Terrorism in Domestic Violence - An Indian Outlook. Medico-Legal Journal. 2012, vol. 80, no. 33, p. 35.

RAVITZ, Jessica. Women in the World: Where the U.S. Falters in quest for equality. [online]. Available at: <http://www.cnn.com/2015/04/16/us/american-women-world-rankings/index.html> Accessed: 09.30.2019

SACHDEV, Chhavi. Rape Is A Crime In India - But There Are Exceptions, NPR.org. [online]. Available at: <http://www.npr.org/sections/goatsandsoda/2016/04/13/473966857/ rape-is-a-crime-in-india-with-one-exception> Accessed: 09.25.2019

SIEGAL, Weintraub Lalenya. The Marital Rape Exemption: Evolution to Extinction, 43 Cleveland State Law Review, 1995, vol. 43, no. 351, p. 356.

SITTON, Jaye. Old Wines in New Bottles: The Marital Rape Allowance, 1993, North Carolina Law Review, vol. 72, no. 261, p. 263.

SMILOWITZ, Ariel. For U.S. Women, Inequality Takes Many Forms. [online]. Available at: $<$ http://www.huffingtonpost.com/ariel-smilowitz/for-us-women-inequality-takesmany-forms_b_7064348.html> Accessed: 09.30.2019

THE WORLD BANK. [online]. Available at: <http://data.worldbank.org/indicator/SL.TLF.TOTL.FE.ZS? end=2016\&locations=IN-US\&start=2016\&view=bar $>$ Accessed: 09.30.2019

The World Factbook, C.I.A. [online]. Available: <https://www.cia.gov/library/publications/resources/the-world-factbook/geos/in.html> Accessed on: 09.25.2019.

USA Today, 4 convicted in fatal gang-rape that shocked India will be hanged. [online]. Available at: <https://www.usatoday.com/story/news/world/2017/05/05/gang-rapeindia-death-sentence/101320278/> Accessed: 09.25.2019

VOLOKH, Eugene. The American tradition of multiculturalism. [online]. Available at: $<$ https://www.washingtonpost.com/news/volokh-conspiracy/wp/2015/01/27/theamerican-tradition-of-multiculturalism/?utm_term=.e41a07156ecc $>$ Accessed: 09.30.2019

Women in the Labour Force: India, Catalyst, [online]. Available at: <http://www.catalyst. org/knowledge/women-labour-force-india> Accessed: 09.30.2019

WOOLLEY, Lee Morgan. Marital Rape: A Unique Blend of Domestic Violence and NonMarital Rape Issues, 2007, Hastings Women's Law Journal, vol. 18, no. 269, p. 272.

WORLD HEALTH ORG., Changing culture and social norms that support violence. [online]. Available at: http://www.who.int/violence_injury_prevention/violence/ norms.pdf> Accessed: 09.30.2019 